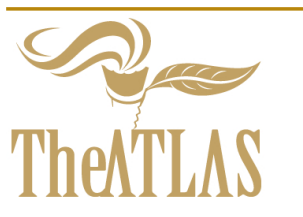

\title{
Transdisciplinary Theater for the Re-enchantment of the Being and the World
}

\author{
Domingo Adame, Veracruzana University, Mexico, Email: domingoadame@yahoo.com
}

Received 15 November, 2018; Revised January 26, 2019 Accepted February 3, 2019

Copyright (C)2019 Domingo Adame. This is an open access article distributed under the Creative Commons Attribution License (https://creativecommons.org/licenses/by/4.0/), which permits unrestricted use, distribution, and reproduction in any medium, provided the original work is properly cited.

Available online February 4, 2019 at www.atlas-journal.org, doi: 10.22545/2019/0115

\begin{abstract}
$n$ this communication I'm interested in answering the question about how the theatre that has transdisciplinarity as its support, can contribute to the "re-enchantment of the being and the world", for its quite clear that the theatrical model legitimated doesn't allow nowadays a satisfying relation with the complexity that constitutes the Subject. I will check, therefore, how the transdisciplinary principles of levels of reality, the included middle and complexity, as well as transdisciplinary attitude based on the conscious and cosmic verticality, can help giving the theatre a quality that, through the Hidden Third, allows the union between Subject and Object, meaning the "Re-enchantment of the being and the world". I'll reference the experiences that have affinity with this goal and I'll point out the characteristics of what I call Transtheatre.
\end{abstract}

Keywords: Theatre, re-enchantment, transtheatre, transdisciplinary methodology, Hidden Third.

\section{Introduction}

In my perception the relation that, as humanity, we have with the world and with ourselves reveals a deep disenchantment, because of it, with the naiveté of the child who still lives in me and with my theatrical academic experience of almost four decades, I ask if theatre can contribute to the re-enchantment of the being and of the world. If we observe the context in which we live and that has been clearly described by philosophers and artists, we hardly might be optimists. The challenge which we face, as well as Basarab Nicolescu indicated, is enormous: Transhumanism, ${ }^{1}$

\footnotetext{
${ }^{1}$ The technological singularity is the basic ground of what is called transhumanism, partly because the technological singularity is blind to human values. Let me make, based upon the transdisciplinary approach, some short considerations about transhumanism. If the transhumanist project will be achieved, human beings will become increasingly more a machine and the machine will become increasingly more human. Transhumans, which some philosophers and ideologists call them, for obvious oratorical precautions, improved humans or ameliorated humans, will constitute a new, bio- technological species. Future society will be divided between transhumans and old humans. In my opinion, the old humans will inevitably be servants of the transhumans. In other way Clive Graham examines "transdisciplinary convergence" in the context of radical evolution and how the performing arts employ elements of genetics, robotics, information technology and nanotech-
} 


\section{Anthropocene ${ }^{2}$ and Panterrorism ${ }^{3}$ [1].}

Nevertheless, the creative potential and of conscience of our humankind can be superior to the destructive one, as long as we allow ourselves to flow with the reality. This way has made it by many scenic creators who, in their respective cultures, have generated proposals to face the disenchantment that produced the modernity and reached its apex in the postmodern era.

For that, in the same way which Bertolt Brecht proclaiming that the theatre of the 20th century would be that of the scientific age [3] -a theatre of the reason opposite of the theatre of the feelingstoday, echoing from different voices, I affirm that theatre of the 21st century will be that of the transdisciplinary age, a theatre for the re-enchantment of the being and of the world, one strategy of creation that several artists and researchers have called Transtheatre indicating with it that is a practice based on the Transdisciplinary Methodology, and not an innovation founded in the same principles of the modern paradigm. Of course that does not eliminate other theatre practices.

\subsection{Transdisciplinary Methodology and Theatre}

The three axioms of the Transdisciplinary methodology: Levels of reality, Logic of the Included Middle

nology (GRIN) for innovations to transform performance and say that "and hyper-reality performances attest to the emergent enhancement of human performance and the rise of the transhuman artist resulting from transdisciplinary convergence" (Clive Graham of the School of Creative and Performing Arts, CQUniversity Australia, speak about the Transdisciplinary convergence in the performing arts [2]).

${ }^{2}$ The word anthropocene is a neologism designating a new geological era, characterized by the fact that the actions of the human species become the dominant geophysical force of our planet as compared with natural geological forces. There is a danger today, for the first time in history concerning the extinction of the entire human species. The survival of the human species is, for a good number of scientists and philosophers, the most important issue of our time. One thing is certain: In Anthropocene, the old and persistent radical distinction between nature and culture is no longer valid. Culture changes nature. Desecration (violation) of nature is thus reaching its peak (pinnacle).

${ }^{3} \mathrm{I}$ introduce the neologism panterrorism to describe a new form of terrorism, without any real connection with a religion. Its aim is to kill the other in order to impose its own power. The panterrorism, more and more present on our planet, is replacing God with the human being. By killing the other, the desire of omnipotence reaches an unpredicted climax. and Complexity, are the support of Transtheatre that finds its objective with the emergence of the Hidden Third.

Nicolescu affirms that Transdisciplinary is a question of a strategy that allows the connection with the ordained movement of Reality [4]. In this way, Transdisciplinarity theatre could be in connection with the ordained movement of the Reality if is seen in a vertical perspective that conduces to the re-enchantment.

Theatre - the most ancient form of religion according to Mircea Eliade [5] - human expression where a person interacts with others while someone else observes them in a shared time and space, as our admired Peter Brook synthesized [6], can have different names in diverse cultures, modify the structure of its relations, to privilegiate one or others of his producers according to the epoch, and use or reject the technological available resources. But beyond all its variables, this practice is a real human space of research where Subject tests all the possibilities of being and enters in relation with the Object as we can see in The Valley of Astonishment (2014), written and directed by Peter Brook and Marie-Hélène Estienne. How has been this relation from the Premodernity to the Cosmodernity [7] and how have the enchantment, the disenchantment lived in such a way that now urges the re-enchantment?

\section{Premodernity}

The rite, notion that precedes theatre was generated in the antiquity, in an "enchanted world" of straight participation, where human beings were not obervants detached from the cosmos, but active participants. The personal destiny was assumed attached to the world's destiny and this relation sustained life itself [8].

According to Nicolás Núñez, creator of Anthropocosmic Theatre, the history of Western theatre until before the Scientific Revolution shows how theatre was alienated of the efficacy of the rite to approach entertainment and the presentation of emotional conflicts [9]. Thus, theatre history, is for this creator the history of the decline from the sacred to the profane.

\section{Modernity}

Starting from the postulates of modern science, the main theories and poetics of theatricality were cre- 
ated.

Martha Toriz points out: "From the nineteenthcentury positivism that postulated that the scientific method wasn't only applicable for nature sciences but also for the study of the human being in society, it was established in Germany on 1923 an institution of theatrical science" [10].

This means that the conception of knowledge, of reality and representation in the fields of the arts and theatre hasn't been much different than sciences, since a paradigm is a way of thinking and acting that support all disciplines.

In the West, until the end of the nineteenth century, theatre was brought under literature. The hegemonic theatrical way was based on a dramatic text and it wasn't until halfway of the twentieth century when other manifestations related with representation-action began gaining ground, with the goal of including, effectively, all kinds of scenic practices linked with the scientific and technological developments and not exclusively the enthroned one by the bourgeois theatre of the nineteenth century.

The theatrical studies were institutionalized in the twentieth century as a "theatrical science", nevertheless, the paradigm that dominated the scientist knowledges since the beginning of modern science on the seventeenth century has been confronted by models, approaches and postulates that oppose to reductionism in order to be concordants with a universe where the inconsistencies, contradictions, antinomies and paradoxes exist.

The theatre of the modern age that, of course, reached extraordinary moments with emblematic figures was stablished based on binary logic, it is worthy to check Georges Banu's profound and touching essay Amour et Désamour du Théâtre [11].

\section{Posmodernity}

Changes in the domain of art happen to be more difficult to assimilate by the receivers and the academic institution -whose objective is to preserve the fundamentals that keep all disciplines-than creators/investigator, that in order to overcome the old debate between, for example: literary theatre vs spectacular theatre, or the most recent: live theatre vs ritual theatre, as well as theatre vs performance, have had to change of reference system.

A breakthrough with modernity's paradigm made emerge "posdramatic theatre" that corresponds, just as Hans Thies Lehmann points out, to European theatre of the late twentieth century. It was meant to change from a lineal and successive perception to a simultaneous one. That search was directed to achieve language autonomy, autonomus theatricality, not "mimetic illusion" [12]. In posdramatic texts the question turned around to "which new possibilities of thinking and representation are rehearsed for the human subject" [13].

In the beginning of the twenty-first century, some positions appear and they affirm a change of paradigm in theatre studies, like Chiel Kattenbelt's, who sustains that contemporary culture has become a mediatic culture (not culture of mediation) and that contemporary artistic practices are more interdisciplinary each time.

In Posmodernity one can watch the mixture of spectacles, performances, digital arts, liquid theatralities, post-theatre, postdramatic theatres, textralities. Summing up: Multi and interdisciplinary theatre.

A concept that emerges precisely from open places because of the multi and interdisciplinarity is performance, used at first by the north American academy to distinguish the scenification act of the written play, which-in this context-is designated as theatre. In this sense Performance Studies impulsed by Richard Schechner have as foundation any kind of human representation. We're talking about a new paradigm that replaces the theatre understood as the representation of written dramas [14]. Richard Schechner, in a recent conference at the Mexico's theatre researcher congress asked the question how to perform in the twenty-first century? In a context that, he said, "seems to be dominated by war and violence in all spheres of life" his response was: "By proposing new ways of channeling creative energy towards the invention of new cultural and political imaginaries, Performance Studies present an alternative to totalitarian and colonialist ideologies. A new Fourth World of aesthetics is emerging, seeking social and cultural change through artistic expression. Examples of this collaborative art of resistance across national and cultural boundaries may be found in the work of several artists throughout the Americas" [15].

Schechner proposed a Manifesto of Fourth World Performance that has four axioms:

1. To perform is to explore, to play, to experiment with new relationships. 
2. To perform is to cross borders. These borders are not only geographical, but emotional, ideological, political, and personal.

3 . To perform is to engage in lifelong active study. To grasp every possibility as a script -something to be played with, interpreted, and reformed/remade.

4. To perform is to become someone else and yourself at the same time. To empathize, react, grow, and change.

In the proposal of the North American theoretician, one can find a relation between the characteristic elements of theatre with performance's, that is why Josette Féral rather use the concept of Performative Theatre.

If there is an art that has been benefited of the achievements of the performance is theatre precisely, since it has adopted some of the founding elements that revolutionized gender: actor turned into a creator, the happening of a scenic action instead of its representation or an illusionist game, an spectacle focused not in a text, but in an image and action, calling the receptivity of the audience, of a of a nature essentially spectacular, or to the perception ways of technology. All these elements that print the theatrical scene a performativity and that nowadays have become very common en most of the western countries (particularly in the United States, Holand, Belgium, Germany, Italy and the United Kingdom), are the main characteristics of what I would call "performative theatre" [16].

\section{Cosmodernity}

Cosmodernity proposes a new conviviality, very different than that one that promotes the homogenization of life patterns and which the cultural agent are the mass-media, especially the television.

According to the Mesoamerican thinking, that remains alive despite any annihilation eagerness, it is more accessible to us to comprehend and assume what Cosmodernity means: that every entity in the universe is defined by its relation with other entities [17] allowing the human being to relate with the Hidden Third. Therefore, the ethic imperative of
Cosmodernity is the union among everyone and with everything [18].

At the moment of fusing Subject and Object, the Hidden Third emerges and crosses all levels of reality and goes to the non-resistance zone, or more precisely to the Transreality, a place where knowledge and Being derive in comprehension.

In the first three phases (premodernity, modernity and posmodernity) there is no emergency of the Hidden Third, like there is in cosmodernity.

With the Nicolescu analysis, as fundamentals in what concern to the relation Subject/Object; and of Erika Fischer-Lichte, about "Re-enchantment of the world" [19], we will have that: in Premodern World, Subject is submerge in the Object (enchanted world): Reality is pre-disciplinary, it's manifestation is the ritual; in the Modern World, Subject and Object are separates: (disenchanted world) Reality is disciplinary and its expression is Theatre in proper sense; meanwhile in Postmodernity, Subject predominate on Object (re- disenchanted World): Reality is post-disciplinary and its vehicle is Performance; Transdisciplinary age is Cosmodern because Subject and Object are linked by the Hidden Third (re-enchantment of the world): Reality is transdisciplinary, and its expression is Transtheatre.

Thus, this historical development reveals how theatre and performance puts distance from the ritual efficacy of the sacred falling towards the profane and mechanical, for that is necessary to return to the source-as Jerzy Grotowski wanted [20]-and enter in contact with the pure energy, that minds Re-enchantment of being and the world.

\section{Central fundaments of Transtheatre}

Transtheatre can be defined as the actions that a person or group realize in a conscious way to answer a question that emerges from the deepest of his being or his community, as I said, is based on the three methodological axioms proposed by Nicolescu.

\subsection{Levels of Reality}

Transtheatre relates or better, transcend, Premodernity, Modernity and Postmodernity scenic practices so that allows producers and assistants to pass along different levels of reality taking conscience of their 
breath, attention and producing the biggest possible energy. The movement that can propitiate the re-enchantment through theatre is vertical, not horizontal; it is not reached in a same level of Reality, where we respond to the development of events in an inertial way.

\subsection{Logic of the Included Middle}

Transtheatre, through the logic of the Included Middle, that integrates the contradiction and allows the spirituality, seeks to join all that keeps us separated from ourselves, from others, from nature and from the cosmos. It admits the contradictions and surpasses the binarism, since it is with the participation of all, not with the exclusion, that could emerge the enclosing and fair world that the comprehension and the convivial promote. For example, the relation actor-spectator that can be exemplified as $a$ (actor) $b$ (spectator): according to classic logic (and classic theatre) $a$ is $a$, therefore $a$ can't be $b$ and there is no third term that can be $a$ and $b$ at the time; in the logic of the Middle Third and in Transtheatre, instead, one proposes: and $a$ and $b$ (and actor and spectator) or nor $a$ nor $b$ (nor actor nor spectator).

\subsection{Complexity}

Complexity is present in all fields of knowledge correspondent to the old principle of universal interdependence, and its emergence, Nicolescu says, gave the coups de grace to the classical vision of the world [21].

Transtheatre has as foundation the complex epistemology principles pointed out by Edgar Morin [22] whose theories are the only compatible ones with the transdisciplinary values:

1. Dialogical: it allows maintaining a duality in the core of the unit. It associates two complementary and antagonist terms at once (orderdisorder).

2. Organizational recursion: A recursive process is that one in which the products and the effects are, at the same time, cause and producers of that thing that produces them (society is produces by the interactions among individuals, but once produced it retroacts on the individuals and produces them). The recursive idea breaks the linear idea of cause/effect
3. Hologramatic: Not only the part is within the everything, but the everything is within the part (vs Reductionism -the part- and holismthe everything-).

Transtheatre organizes itself by disintegrating itself, each participant is autonomous and dependent of others at once, one experiments freedom and at the same time one recognizes being possessed by hidden forces, uncertainty is present: there is no absolute order.

Transtheatre is not "spectacle pure", but a multiple dialog among disciplines, poetics and cultures. It is a question of actions managed by re-enchanted subjects by the humility, the innocence and the love, where the structure is auto-poetic and is beyond the rules and conventions of the mimetic representation.

\section{The Hidden Third}

Following Nicolescu I affirm that Transtheatre is a route to look for the unique thing that is worth a sorrow in this world: the Hidden Third.

When the Hidden Third appears all the levels of reality resound. A perpetual movement of energy appears in the shape of vibration, the experience of the present takes place.

Between inhaling and exhaling there appears the Hidden Third, term of interaction between the internal and external world. It is by means of the conscience of the breathing that can change our mentality.

Transtheatre is the theatre of the Sacred and of the infinitely conscious, just like Artaud, Grotowski, Brook, Valencia, Núñez visualized, as well as the Eastern millenial cultures and the ones from Mesoamerica.

The way of the interior knowledge is not tied to any religious or spiritual ideology, is a essential epistemic vigilance of the life and of knowing that it wakes little interest up in the majority of people, because it implies a work and a rigor that is not attractive in general, since we live in a utilitarian world with short vision.

Because of it Transdisciplinarity considers the "Sacred to be a part of a new manner of being, where the reason is not excluded. 


\section{Others characteristics}

\subsection{Transcultural}

Transtheatre is opened for all the differences. It's by means of the Hidden Third that propitiates the comprehension between languages and cultures. "It is the open totality of the human being that constitutes the place without place of that which crosses and transcends cultures" [23].

\subsection{Ethics}

Transtheatre, for being transdisciplinary, is the art of stretching bridges for a better comprehension between people and a better relation with nature. It implies an ethical attitude of opening and dialog, because of it, it can stretch bridges towards the physical, emotional and intellectual balance of the Subject to reconstruct, from the honesty and the commitment, those social, environmental, cultural and affective bows that place people in a plot of fundamental relations to understand and to promote its integral care.

\subsection{Harmony between Feminine and Masculine Energies}

The human institutions of the antiquity and of the modernity have the stamp of the androcentric and only from the Postmodern age the perspective of genre began to generate one fail, but its in the Cosmodernity where one tries to recognize the equality of genres. The androcentric considers the human being of masculine sex to be the center of the universe, the measure of all the things, the only observant valid of everything that happens in the world. This way, in very diverse social, cultural, academic, political spaces, etc., there prevails the masculine presence and the patriarchal vision, being evident a social frame of asymmetries and inequalities. This procedure forgets that the masculine is in the feminine and vice versa. So, Transtheatre seeks to end with the representations, images and speeches that the stereotypes of genre reaffirm co - constructing new statements between human beings.

\subsection{Participative Event}

Transtheatre does not try to re-enchant with the spectacular magnificence, nor on intellectual creation, but for its simplicity, honesty and humility of its events. With the zeal to contribute to the reenchantment of the world it is necessary to recognize the existence of subtle and universal interconnections between all the events and levels of organization of the reality. Each event is unique and unrepeatable, because not remain attached to representations.

\subsection{Transpoetic Creativity}

According to the transdisciplinary principles it's possible to visualize a theatre for and to the creation and recreation of knowledge as to know sensitively that it provides to the existence of its more beautiful attributes and allows the comprehension of the world in its diverse realities. A theatre that allows the emergency of synergies that transforms the destructive fatality into creator destiny. "An aesthetic and also ethic act, the act of revelation of the poetic dimension of existence" [24]. I conceive Transtheatre as a celebration of the humanity, as a space of reconnection with everything living and as a manifestation of the surprising individual and collective creativity.

\subsection{Transtheatre as Food}

What food do we want to offer to our society? Only distraction and scattering, or an experience that favors the self-knowledge and the interior expansion?

Transtheatre tries to re-enchant transform into food of the first quality for the spirit. "A theatrical event without concessions would be a delicious piece of manna offered by their officiates, it provokes the internal flight and the expansion of the conscience" as Nicolás Núñez say [25]. Transtheatre is made for giving food, for the soul, for the spirit, for spiritual life.

\subsection{Conscience of Being Universe}

Transtheatre is a theatre of transdisciplinary fusion that allows us to discover integrated, assembled with the universe. The theatre promoter of the consumerism is a theatre that fissions, it breaks, isolates. A theatre of transdisciplinary fusion is a theatre that sings and re-enchanted. We are in the universe and we are universe.

To understand this earth and cosmic identity not only constitutes an individual, but familiar, social and spiritual health what it means to recognize theatre as a force of interaction with the universe. To 
understand it is to honor, on one hand, the theatrical lineage that there inherited: Zeami, Shakespeare, Stanislavski, Meyerhold, Artaud, Brecht, Grotowski, Beckett, Ionesco, Brook, Valencia, Serban and, for other one, the lineage of the deep knowledge illuminated by beings as Gurdjieff, Krisnhamurti, Edgar Morin, Basarab Nicolescu, Lee Worley and Antonio Gómez Yepes, among others.

\section{Invisible Bridges as Example of Transdisciplinary Theatre for the re-enchantment of the being and the world}

Invisible bridges, was an trans theatrical event that was raising the need to establish deep contact with ourselves, with other ones and with the world, it was based on Citlalmina's origin dance that fuses the Tibetan of The black hat with the Mexican ritual and that from 1986 the Workshop of Theatrical Research (TIT) of UNAM uses as psychophysical training for actors and not actors. The text recounts across traditional Tibetans stories how Citlalmina arose. The event developed in two stages, first a tour for Chapultepec's thousand-year-old forest in Mexico city inviting the assistants to the communion with the trees and, later, in the clear one of the forest where the history was spreading out and there were carried out a series of participative actions created by the members of the TIT.

\subsection{Transdisciplinarity in Invisible Bridges}

Who were part in Invisible Bridges worked with the premise of connecting with our cosmic and conscious verticality, this meant to have the disposition to pass simultaneously along different levels of reality, we assume our bio - psychic condition as individuals being employed collectively at a space that was connecting us with our belonging to a sociocultural area: Mexico and its pre-Hispanic precedents - Chapultepec's Forest - and with the intention of linking ourselves in the planetary level - with another space: the Tibet. The event developed, in addition, in connection with the land, with the trees and with the stars, that is to say in a cosmic level. This verticality made possible to overcome the separation between us as Subjects with the Object with which we were in relation. We were people joined by the individual and collective urgency of connecting across the Hidden Third with the Real. We gave mutually feedback of energy and creativity.

As for the logic of the Included Middle, we were conscious that we were, at the same time, actors and not actors, rather transactors. The complexity was residing in establishing dialogical, recursive and hologrammatic relations [26] to unify the levels of reality. In Invisible Bridges one was giving a dialog opened between languages, actions and realities; there was a circularity of cause-effect-cause and as well as we were recognizing ourselves forming part of the universe the universe were in us.

\section{Concluding Remarks}

Already it is not longer possible to continue increasing neither the pain of our so injured humanity, nor the suffering of our motherland. I feel that a new birth is increasingly urgent. It is no longer a matter of waiting for the arrival of the "new man" who, wanted the modernity, would be the result of an egalitarian and prosperous society. Is in every transtheatrical circle, breathing together with the same step, interlacing our bodies, looking at the eyes to recognize ourselves, dancing and singing with verticality, that we can give place to this new birth to restart later, with happiness in our hearts, the way without way of the infinitely human.

Transdisciplinary theatre makes us live reenchanted and in a re-enchanted world that allows us to feel that we form a part of the infinite energy connected with everything that exists.

Funding: This research received no external funding.

Conflicts of Interest: The author declare no conflict of interest.

\section{References}

[1] Nicolescu, B. Technological Singularity - The Dark Side. http://www.atlas-journal.org/index.php/term2/2016-issue?download=99:technologicalsingularity-the-dark-side (accessed October 30, 2018).

[2] Graham, C (2011). Transdisciplinary convergence in the performing arts. Studies in Learning, Evaluation, Innovation and Development, 8(2), 26-39.

[3] Brecht, B., (1970). La Poltica en el teatro. Buenos Aires: Alfa. 
[4] Núñez, C., Rehaag, I., Sánchez, A. \& Vargas, E. (Eds.), (2011). Transdisciplinariedad y Sostenibilidad: Encuentro con Basarab Nicolescu. Xalapa, Veracruz: Editores de la Nada.

[5] Eliade, M., (1981).Lo Sagrado y lo Profano. Madrid: Guadarrama.

[6] Brook, P., (1986). El Espacio Vacío. Barcelona: Ediciones Península.

[7] Nicolescu, B., (2014). From Modernity to Cosmodernity - Science, Culture, and Spirituality. New York: State University of New York Press.

[8] Berman, M., (2001). El Reencantamiento del mundo. Santiago de Chile: Cuatro Vientos.

[9] Middleton, D. (2011). "Sacralidad secular" en el teatro ritual del Taller de Investigación Teatral de la UNAM. In Adame, Domingo (coord.) y Antonio Prieto (edit.). 2011. Jerzy Grotowski. Miradas desde Latinoamérica. Xalapa: Universidad Veracruzana.

[10] Toriz, M., (2009). La teatrología y las artes escénicas. In D. Adame (Ed.), Actualidad de las Artes Escénicas: Perspectiva Latinoamericana. (pp. 80-83) Xalapa: Universidad Veracruzana.

[11] Banu, G., (2013). Amour et Désamour du Théâtre. France Paris: Actes Sud.

[12] Lehmann, H., (2010). Le Théâtre Postdramatique. (p. 20) Paris: L'Arche.

[13] Lehmann, H., (2010). Le Théâtre Postdramatique. (p. 21) Paris: L'Arche.

[14] Schechner, R., (2002). Performance Studies: An Introduction. New York: Routledge.

[15] Schechner, R., (2017). ¿Cómo performar en el Siglo XXI?.Investigación Teatral, 7(10-11), 11-23.

[16] Féral, J., (2017). Por una Poética de Performatividad: El Teatro Performativo. Investigación Teatral, 7(10-11), 25-50.

[17] Nicolescu, B., (2014). From Modernity to Cosmodernity - Science, Culture, and Spirituality. New York: State University of New York Press.

[18] Nicolescu, B., (2014). From Modernity to Cosmodernity Science, Culture, and Spirituality. (p. 314) New York: State University of New York Press.

[19] Fischer-Lichte, E., (2008). The Transformative Power of Performance: A New Aesthetics. London and New York: Routledge.

[20] Grotowski, J., (1976). Hacia un Teatro Pobre. México: Siglo XXI.

[21] Nicolescu, B., (2014). From Modernity to Cosmodernity Science, Culture, and Spirituality. New York: State University of New York Press.

[22] Morin, E., (2003), Introducción al Pensamiento Complejo. Barcelona, Spain: Gedisa.
[23] Nicolescu, B., (2009). La Transdisciplinariedad: Manifiesto. (p. 78) Hermosillo, Mexico: Multidiversidad Mundo Real Edgar Morin.

[24] Nicolescu, B., (2009). La Transdisciplinariedad: Manifiesto. (p. 68) Hermosillo, Mexico: Multidiversidad Mundo Real Edgar Morin.

[25] Adame, D. \& Núnez, N., (2018). Transteatro. Entre, a través y mas allá del Teatro. (p. 7) Buenos Aires: Argus-a.

[26] Morin, E., (2003), Introducción al Pensamiento Complejo. Barcelona, Spain: Gedisa.

\section{About the Author}

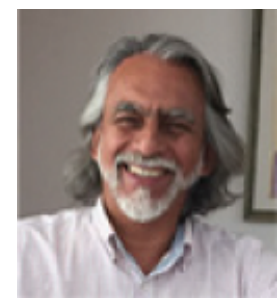

Dr. Domingo Adame received bachelor in Dramatic Literature and Theater by Autonomous National University of Mexico UNAM (1983), Master in Literary Studies by Autonomous University of State of Mexico (1993) and PhD by Iberoamericana University (2001), has followed a course of specialization in performance and theatrical direction in Theater School of Krakow, Poland (1985-86). He has worked as actor, director, professor and theatrical researcher in several institutions of higher education of the country. From 2001 until now is professor-researcher in Veracruzana University in Xalapa, Mexico. Has been Director of the National Centre of Theatrical Research Rodolfo Usigli of The National Institute of Fine Arts (1989-1993), Founder President of Mexican Association of Theater Research (1993), Director of the Theater Faculty of The Veracruzana University (2005-2009), was Director of the Magazine Theatrical Research of The Veracruzana University and Mexican Association of Theater Research. 